\title{
Multiple osteochondromas
} Judith VMG Bovée

\author{
Address: Department of Pathology, Leiden University Medical Center, Leiden, The Netherlands \\ Email: Judith VMG Bovée - j.v.m.g.bovee@lumc.nl
}

Published: 13 February 2008

Orphanet Journal of Rare Diseases 2008, 3:3 doi:10.1 186/I750-1 I72-3-3

This article is available from: http://www.ojrd.com/content/3/I/3

(c) 2008 Bovée; licensee BioMed Central Ltd.

This is an Open Access article distributed under the terms of the Creative Commons Attribution License (http://creativecommons.org/licenses/by/2.0), which permits unrestricted use, distribution, and reproduction in any medium, provided the original work is properly cited.
Received: 13 November 2007

Accepted: 13 February 2008

\begin{abstract}
Multiple osteochondromas (MO) is characterised by development of two or more cartilage capped bony outgrowths (osteochondromas) of the long bones. The prevalence is estimated at 1:50,000, and it seems to be higher in males (male-to-female ratio 1.5:I). Osteochondromas develop and increase in size in the first decade of life, ceasing to grow when the growth plates close at puberty. They are pedunculated or sessile (broad base) and can vary widely in size. The number of osteochondromas may vary significantly within and between families, the mean number of locations is 15-18. The majority are asymptomatic and located in bones that develop from cartilage, especially the long bones of the extremities, predominantly around the knee. The facial bones are not affected. Osteochondromas may cause pain, functional problems and deformities, especially of the forearm, that may be reason for surgical removal. The most important complication is malignant transformation of osteochondroma towards secondary peripheral chondrosarcoma, which is estimated to occur in $0.5-5 \%$. MO is an autosomal dominant disorder and is genetically heterogeneous. In almost $90 \%$ of $\mathrm{MO}$ patients germline mutations in the tumour suppressor genes EXTI or EXT2 are found. The EXT genes encode glycosyltransferases, catalyzing heparan sulphate polymerization. The diagnosis is based on radiological and clinical documentation, supplemented with, if available, histological evaluation of osteochondromas. If the exact mutation is known antenatal diagnosis is technically possible. MO should be distinguished from metachondromatosis, dysplasia epiphysealis hemimelica and Ollier disease. Osteochondromas are benign lesions and do not affect life expectancy. Management includes removal of osteochondromas when they give complaints. Removed osteochondromas should be examined for malignant transformation towards secondary peripheral chondrosarcoma. Patients should be well instructed and regular follow-up for early detection of malignancy seems justified. For secondary peripheral chondrosarcoma, en-bloc resection of the lesion and its pseudocapsule with tumour-free margins, preferably in a bone tumour referral centre, should be performed.
\end{abstract}

\section{Disease name and synonyms}

Multiple Osteochondromas (MO) MIM 133700

Hereditary Multiple Exostoses (HME), Multiple Hereditary Exostoses (MHE), EXT, diaphyseal aclasis, (multiple hereditary) osteochondromatosis, multiple cartilaginous exostoses

\section{Definition and diagnostic criteria}

Osteochondroma (osteocartilaginous exostosis) is a cartilage capped bony projection arising on the external surface of bone containing a marrow cavity that is continuous with that of the underlying bone [1]. A diagnosis of $\mathrm{MO}$ can be made when radiologically at least two osteochondromas of the juxta-epiphyseal region of long 
bones are observed. In the majority of patients a positive family history and/or mutation in one of the EXT genes can be detected $[2,3]$.

\section{Epidemiology}

The prevalence of $\mathrm{MO}$ is estimated at 1:50,000 persons within the general population [4] and seems to be higher in males (male-to-female ratio 1.5:1) [2,5]. This is probably due to the fact that females tend to have a milder phenotype and are therefore more easily overlooked [2]. The solitary (sporadic) form of osteochondroma is approximately six times more common than the occurrence within the context of MO. Approximately $62 \%$ of the patients with multiple osteochondromas have a positive family history [2].

\section{Clinical description}

Osteochondromas develop and increase in size in the first decade of life, ceasing to grow when the growth plates close at puberty. They are pedunculated or sessile (broad base) and can vary widely in size. The majority are asymptomatic and located in bones that develop from cartilage, especially the long bones of the extremities, predominantly around the knee (Figures 1 and 2A). The facial bones are not affected. The number of osteochondromas may vary significantly within and between families, the mean number of locations is 15-18 [6]. In addition, in $\mathrm{MO}$ patients a variety of orthopaedic deformities can be found like deformities of the forearm (shortening of the ulna with secondary bowing of radius) $(39-60 \%)[4,6,7]$ (Figure 2C), inequality in limb length $(10-50 \%)[4,7]$, varus or valgus angulation of the knee $(8-33 \%)[4,7]$,

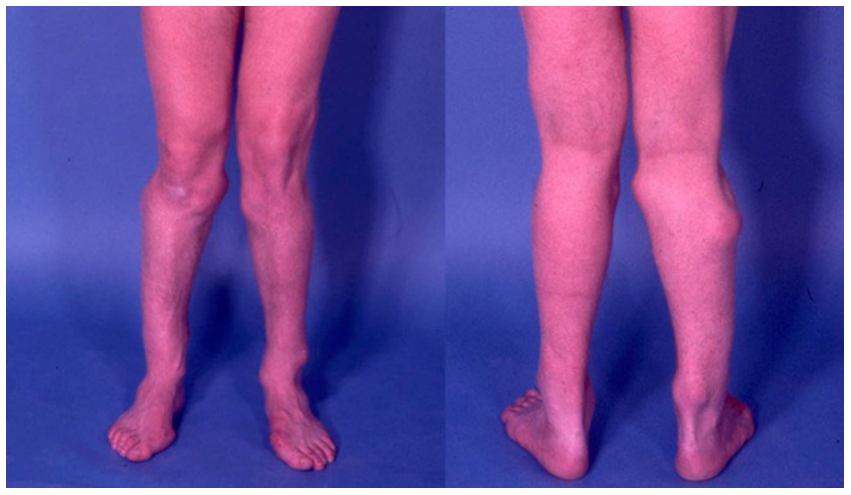

Figure I

Photograph of the legs of a 26 year old male showing multiple lumps leading to deformity.

deformity of the ankle (2-54\%) $[4,7]$ and disproportionate short stature $(37-44 \%)[2,5,6]$.

Other complications of the osteochondromas include osseous and cosmetic deformities, bursa formation, arthritis (14\%) [5] and impingement on adjacent tendons, nerves $(22.6 \%)$ [5], vessels $(11.3 \%)$ [5] or spinal cord $(0.6 \%)[5,8]$. MO patients may have abnormal scar formation [9]. Osteochondromas bear the risk for fracture of the bony stalk during physical exercise. This is estimated to occur in approximately $5 \%$ of osteochondromas [10] and may be reason for surgical removal.

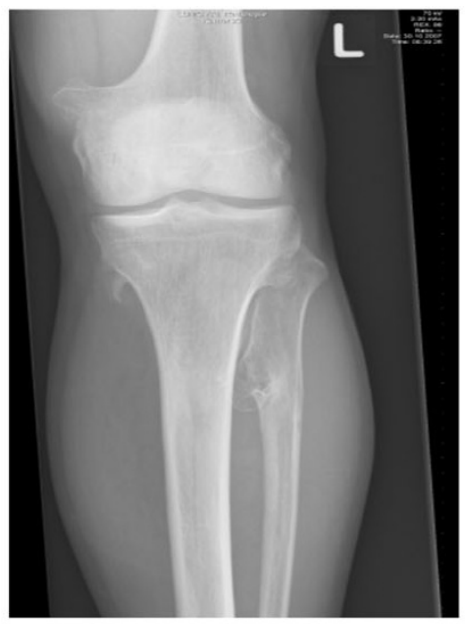

A

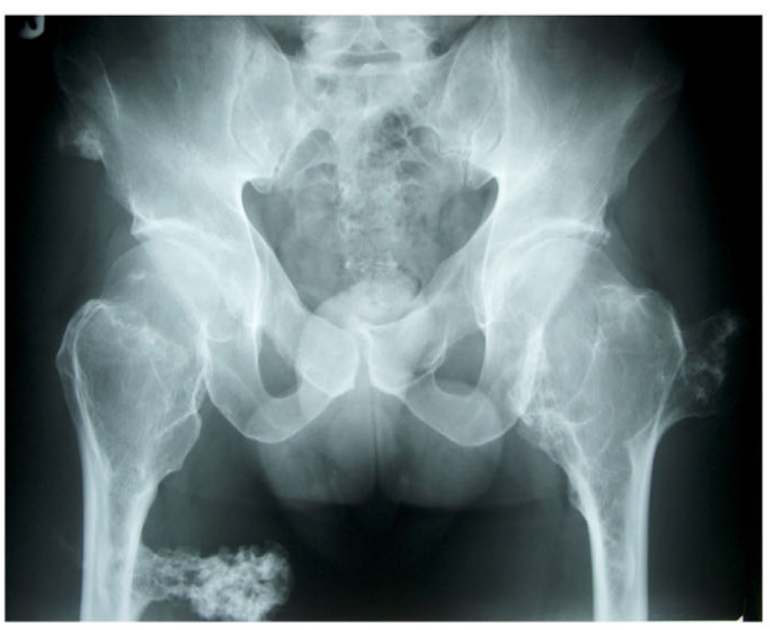

B

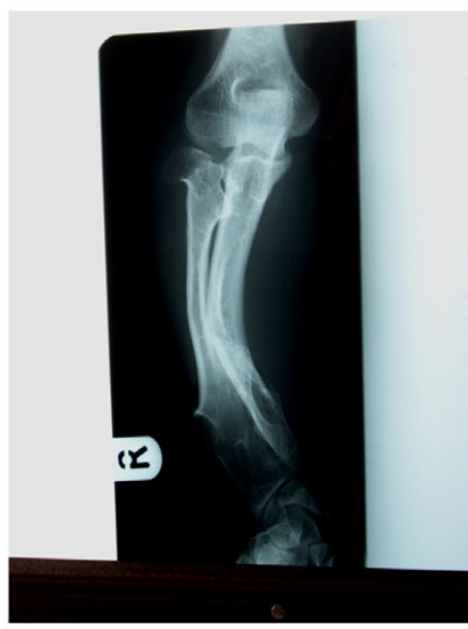

C

\section{Figure 2}

Examples of radiographs demonstrating multiple osteochondromas around the knee (A) and at the pelvis and proximal femur (B), while (C) demonstrates the deformity of the forearm (shortening of the ulna with secondary bowing of radius) that is found in $39-60 \%$ of the patients. 
The majority of MO patients experiences pain [11,12], approximately half of which concerns generalised pain [11]. Therefore, the number of $\mathrm{MO}$ individuals having pain has been underestimated and pain seems a problem that must be addressed when caring for MO patients. The occurrence of pain was associated with MO related complications and surgery [11].

The most important complication of $\mathrm{MO}$ is malignant transformation of an osteochondroma, which is estimated to occur in $0.5-5 \%$ of patients $[2,4,5,13,14]$. Clinical signs of malignant transformation include an increase in size and pain [6]. Malignant transformation of osteochondroma leads to a secondary peripheral chondrosarcoma in $94 \%$ of the cases [15]. The suspicion of secondary chondrosarcoma is indicated by growth of the tumour after puberty, the presence of pain, or a thickness over 1 $\mathrm{cm}$ of the cartilaginous cap in adults.

\section{Aetiology}

Two genes, EXT1 and EXT2 located respectively at 8q24 and 11p11-p12, have been isolated to cause MO [16-19]. Additional linkage to chromosome 19p has been found, suggesting the existence of an EXT3-gene [20]. However, the gene has never been identified. Moreover, the increased sensitivity of mutation detection and the use of new techniques screening for larger deletions, such as MLPA, have dramatically decreased the proportion of $\mathrm{MO}$ patients without an EXT1 or EXT2 mutation to <15\% [2123]. These data question the existence of an EXT3-gene at $19 \mathrm{p}$.

The EXT1 gene is composed of 11 exons and has a coding region of 2238 bp [17-24]. The EXT2-gene contains 16 exons $[18,19]$ and its CDNA defines a single open reading frame of $2154 \mathrm{bp}$. EXT1 and EXT2 are highly similar, especially in the carboxy terminal region $[18,19]$.

The EXT1 gene was reported to show linkage in $44 \%-66 \%$ of the MO families $[25,26]$, whereas EXT2 would be involved in $27 \%$ [26]. Germline mutations of EXT1 and EXT2 in MO patients have been studied extensively in Caucasian as well as Asian populations [27]. In EXT1, mutations are more or less randomly distributed over the first 6 exons, while the last 5 exons, containing the conserved carboxyterminal region, contain significantly less mutations [27]. Similarly, in EXT2 most mutations are found in the first eight exons. No mutational hotspots are found. Approximately $80 \%$ of the mutations are either non-sense, frameshift, or splice-site mutations leading to premature termination of EXT proteins [25,28-32]. The majority of missense mutations also lead to defective EXT protein function [33]. Mutations in EXT1 seem associated with a more severe phenotype as compared to EXT2 [3437].
It has long been thought that osteochondromas are the result of skeletal dysplasia. It is now however generally accepted that osteochondromas are neoplastic, since genetic changes are found in the cartilage cap [1,38-42]. The EXT-genes are tumour suppressor genes. Loss of the remaining EXT1 wildtype allele has been demonstrated in the cartilage cap of osteochondromas from MO patients [39]. However, in a considerable proportion of $\mathrm{MO}$ patients loss of the remaining wildtype allele could not be detected so far [43]. In seven out of eight solitary osteochondromas, homozygous deletions of EXT1 are found [38] further supporting the two-hit model. Moreover, the deletions were confined to the cartilage cap. Thus, the cartilage cap is the clonal neoplastic element, while the stalk is reactive [38].

Both EXT1 and EXT2 mRNA is ubiquitously expressed [17-19]. A high level of expression of Ext1 and Ext2 mRNA has been found in developing limb buds of mouse embryos [44,45] and expression was demonstrated to be confined to the proliferating and prehypertrophic chondrocytes of the growth plate [46]. In osteochondromas and peripheral chondrosarcomas the expression of EXT1 and/or EXT2 is decreased, corresponding to the mutation status [47].

The gene products, exostosin-1 (EXT1) and exostosin-2 (EXT2), are endoplasmic reticulum localized type II transmembrane glycoproteins which form a Golgi-localised hetero-oligomeric complex that catalyzes heparan sulphate (HS) polymerization [48-51]. Heparan sulphate proteoglycans (HSPG) are large macromolecules composed of heparan sulphate glycosaminoglycan chains linked to a protein core. Four important HSPG families are syndecan, glypican, perlecan and isoforms of CD44 bearing variable exon $3(\mathrm{CD} 44 \mathrm{v} 3)$. In osteochondromas in which EXT expression is decreased due to mutation or deletion, the heparan sulphate proteoglycans seem to accumulate in the cytoplasm of the cell, instead of being transported to be expressed at the cell surface [47].

EXT and HSPGs are required for high-affinity binding of fibroblast growth factor to its receptor and for the diffusion of the morphogens Hedgehog (Hh, human homologues Indian (IHH) and Sonic Hedgehog (SHH) [52-54], decapentaplegic (dpp, human homologues TGF-beta and $\mathrm{BMP}$ ) and wingless (wng, human homologue Wnt) $[55,56]$. These three pathways are important during development and are specifically active in the growth plate during endochondral bone formation. During normal growth, IHh and PTHLH are involved in a delicate paracrine feedback loop regulating proliferation and differentiation of the chondrocytes of the growth plate (Figure 3 ). In osteochondroma, IHH signalling is still active and is probably cell autonomous $[57,58]$. PTHLH signalling, 


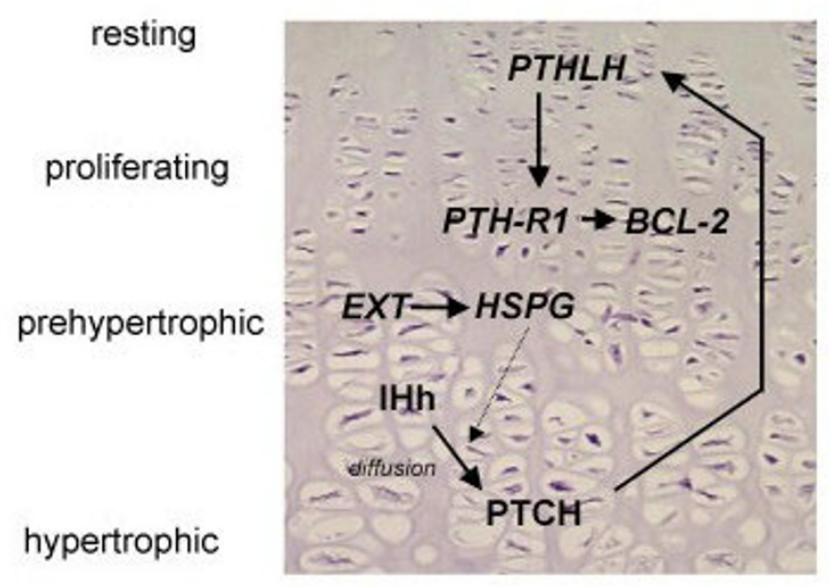

Figure 3

Growth plate signaling in the normal growth plate. Indian Hedgehog protein (IHh) is expressed in the prehypertrophic cells, and diffuses over a variable distance to its receptor Patched (PTCH). Subsequently, increased secretion of ParaThyroid Hormone Like Hormone (PTHLH) is induced at the apical perichondrium via an incompletely understood mechanism. PTHLH then diffuses to its receptor, whose expression is restricted to the late proliferating chondrocytes, inhibiting their further differentiation, resulting in less IHh producing cells, which closes the feedback loop. Thus, PTHLH regulates the pace of chondrocyte differentiation by delaying the progression of chondrocytes towards the hypertrophic zone, allowing longitudinal bone growth. Defective or absent EXT proteins leading to altered or absent HSPG expression at the cell surface may affect this negative feedback loop by disturbing the diffusion of $\mathrm{IHh}$, produced at the pre-hypertrophic chondrocytes, towards its receptor Ptc.

which is downstream of $\mathrm{IHH}$ and is responsible for chondrocyte proliferation, is absent in osteochondroma, while being upregulated upon malignant transformation of osteochondroma $[59,60]$. Wnt signalling and TGF-beta signalling are also active in the majority of osteochondromas [57]. The exact role of EXT in orchestrating these pathways leading to osteochondroma formation in $\mathrm{MO}$ patients needs to be further elucidated.

\section{Diagnostic methods}

When a patient is suspected to have $\mathrm{MO}$, the full radiological documentation, histology (if available), patient history and family history have to be carefully reviewed. Given the specific radiological and histological expertise needed, and the rarity of the disorder and of those in the differential diagnosis, it is recommended that this review is performed by specialists in the field, for instance through a national bone tumour registry consisting of clinicians, radiologists and pathologists. If this review is indicative for $\mathrm{MO}$, the peripheral blood of the patient may be screened for germline mutations in EXT1 or EXT2 [61].
In case of a positive family history in which $\mathrm{MO}$ is clearly established in relatives, the diagnosis of MO can be clinically made and mutation analysis is not essential. With the currently used methods it is possible to detect point mutations or gross deletions in almost $90 \%$ of $\mathrm{MO}$ patients [21-23,61-63].

To evaluate possible malignant transformation in case of complaints or growth of the lesion after puberty, the size of the cartilaginous cap can be well established with T2weighted magnetic resonance (MR) imaging [64]. A cartilage cap $>1.5 \mathrm{~cm}$ should be regarded with caution. The role of 18 Fluoro-deoxyglucose positron emission tomography (18FDG PET) needs to be further established [65].

\section{Differential diagnosis}

Dysplasia Epiphysealis Hemimelica (DEH, Trevor's disease, tarso-epiphysial aclasis) and metachondromatosis (MC) are considered in the differential diagnosis of solitary and hereditary osteochondromas. Despite their similarities, they were shown to be separate entities [66] and the EXT downstream pathway is not involved [67].

DEH is a developmental disorder with cartilaginous overgrowth of a portion of one or more epiphyses [68]. It predominantly affects the lower extremity on one side of the body. It is usually restricted to either the medial (most frequent) or lateral side of the limb (hemimelic). Similar to osteochondroma, DEH is usually diagnosed prior to the age of 15 years, more often in boys than in girls, and growth of these lesions end at puberty as the growth plates close $[68,69]$. In contrast to MO, malignant transformation has not been reported so far [68] and there does not appear to be any genetic transmission [69-71].

$\mathrm{MC}$ is a rare disorder exhibiting, synchronous, both multiple osteochondromas and enchondromas in children. It has an autosomal dominant mode of inheritance [72-74] but the disorder has not been mapped in the human genome so far. MC related osteochondromas characteristically occur in the hands and feet, predominantly the digits and toes, and point toward the adjacent growth plate, while in $\mathrm{MO}$ the osteochondromas are mainly located in the long or other tubular bones and point away from the epiphysis [72]. Differentiation from MO is of great clinical significance because in patients with MC the lesions do not result in shortening or deformity of affected bones as in $\mathrm{MO}$, and may spontaneously decrease in size or resolve completely, both clinically and radiologically $[72,74]$.

Moreover, MO should be distinguished from enchondromatosis (Ollier disease and Maffucci syndrome), in which multiple cartilage tumours are found in the medulla of bone, with a predilection for the short tubular bones and a unilateral predominance [75]. 
Upon histopathological examination of osteochondroma after surgical removal malignancy should be considered. Malignant transformation in the cartilage cap of osteochondroma leads to a secondary peripheral chondrosarcoma. Occasionally, osteosarcomas and spindle cell sarcomas develop in the stalk of the osteochondroma [15,76-80]. Extremely rare is the occurrence of dedifferentiated peripheral chondrosarcoma, in which a low-grade chondrosarcoma that developed within an osteochondroma "dedifferentiates" into a high grade sarcoma $[81,82]$.

\section{Genetic counselling}

$\mathrm{MO}$ is an autosomal dominant disorder. Affected individuals have $50 \%$ risk of transmitting the disorder to their offspring. MO has nearly $100 \%$ penetrance. If the exact mutation is known antenatal diagnosis is technically possible.

\section{Management including treatment}

Osteochondromas are only removed when they cause pain, when they give functional complaints for instance due to compression on nerves or vessels, or for cosmetic reasons.

Surgical treatment of forearm deformities remains controversial. In a retrospective series $23 \mathrm{MO}$ patients corrective osteotomy and/or lengthening of forearm bones was not beneficial [83]. Moreover, one should consider the possible recurrence of ulnar shortening within 1.5 years when operating skeletally immature patients $[83,84]$. The most beneficial procedure was excision of the osteochondromas. The simple removal of an osteochondroma can improve forearm rotation and correct deformity [83], especially if there is an isolated tumour of the distal part of the ulna.

If the diagnosis of $\mathrm{MO}$ is established and all tumours are identified, patients should be well instructed to seek earlier medical attention if their condition changes, for instance if there is pain or growth of a known lesion [61]. It is important to realise that no new osteochondromas develop after puberty. Moreover, regular follow-up to discover potential malignant transformation at an early stage to enable adequate treatment should be considered. The risk of malignant transformation of osteochondroma towards secondary peripheral chondrosarcoma is estimated at $1-5 \%[2,4,5,13,14,34]$. After skeletal maturation a base-line bone scan is recommended [61]. Furthermore, baseline plain radiographs of areas that can not be manually examined, like the chest, pelvis and scapula can be performed [61]. After the base-line documentation one should consider screening patients regularly, for instance every year or every other year. There are as yet no studies available that have proven efficacy of screening. If lesions change over time, further examination, using magnetic resonance (MR) imaging including contrast enhanced MR sequences, is indicated [61].

In case of malignancy, en-bloc resection of the lesion and its pseudocapsule with tumour-free margins, preferably in a bone tumour referral centre, should be performed, resulting in excellent long term clinical and local results. The most common location is however the pelvis where the large cartilage cap can be difficult to excise. In a series of 61 patients with grade I or II secondary peripheral chondrosarcoma of the pelvis published by Donati et al., a 3\% local recurrence rate was found after wide resection, in contrast with $23 \%$ after inadequate excision [85].

\section{Prognosis}

Osteochondromas are benign lesions and do not affect life expectancy. The risk of malignant transformation is $1-5 \%$. The prognosis for secondary peripheral chondrosarcoma is depending on histological grade: 10 year survival rates are $83 \%$ for grade I chondrosarcomas compared to $29 \%$ for grade III chondrosarcomas [86].

\section{Unresolved questions}

- How can the enormous difference in disease severity within and between families be explained?

- What drives malignant transformation of osteochondroma and can this be prevented?

- What is the role of EXT in normal cartilage growth and differentiation and in osteochondroma formation?

\section{Acknowledgements}

The author would like to thank Prof. Dr. A.H.M. Taminiau, Department of Orthopaedic Surgery, Leiden University Medical Center and Dr. S.J. Ham, Department of Orthopaedic Surgery, Onze Lieve Vrouwe Gasthuis Amsterdam for providing figures I and 2.

\section{References}

I. Khurana J, Abdul-Karim F, Bovée JVMG: Osteochondroma. In World Health Organization classification of tumours. Pathology and genetics of tumours of soft tissue and bone. Edited by: Fletcher CDM, Unni KK and Mertens F. Lyon, IARC Press; 2002:234-236.

2. Legeai-Mallet L, Munnich A, Maroteaux P, Le Merrer M: Incomplete penetrance and expressivity skewing in hereditary multiple exostoses. Clin Genet 1997, 52:12-16.

3. Bovée JVMG, Hogendoorn PCW: Multiple osteochondromas. In World Health Organization classification of tumours. Pathology and genetics of tumours of soft tissue and bone. Edited by: Fletcher CDM, Unni KK and Mertens F. Lyon, IARC Press; 2002:360-362.

4. Schmale GA, Conrad EU, Raskind WH: The natural history of hereditary multiple exostoses. J Bone Joint Surg [Am] 1994, 76(7):986-992.

5. Wicklund LC, Pauli RM, Johnston D, Hecht JT: Natural history study of hereditary multiple exostoses. Am J Med Genet 1995, 55:43-46.

6. Hennekam RC: Hereditary multiple exostoses. J Med Genet 1991, 28:262-266.

7. Shapiro F, Simon S, Glimcher MJ: Hereditary multiple exostoses. Anthropometric, roentgenographic, and clinical aspects. J Bone Joint Surg Am 1979, 6 1:81 5-824. 
8. Vanhoenacker FM, Van Hul W, Wuyts W, Willems PJ, De Schepper AM: Hereditary multiple exostoses: from genetics to clinical syndrome and complications. Eur J Radiol 200I, 40:208-2I7.

9. Hosalkar H, Greenberg J, Gaugler RL, Garg S, Dormans JP: Abnormal scarring with keloid formation after osteochondroma excision in children with multiple hereditary exostoses. Pediatr Orthop 2007, 27:333-337.

10. Carpintero P, Leon F, Zafra M, Montero M, Berral FJ: Fractures of osteochondroma during physical exercise. Am J Sports Med 2003, 31:1003-1006

II. Darilek S, Wicklund C, Novy D, Scott A, Gambello M, Johnston D, Hecht ]: Hereditary multiple exostosis and pain. J Pediatr Orthop 2005, 25:369-376

12. Bottner F, Rodl R, Kordish I, Winklemann W, Gosheger G, Lindner $\mathrm{N}$ : Surgical treatment of symptomatic osteochondroma. A three- to eight-year follow-up study. J Bone Joint Surg Br 2003, 85: $1161-1165$

13. Gordon SL, Buchanan JR, Ladda RL: Hereditary multiple exostoses: report of a kindred. J Med Genet I98I, 18:428-430.

14. Peterson HA: Multiple hereditary osteochondromata. Clin Orthop 1989, 239:222-230.

15. Willms R, Hartwig CH, Böhm P, Sell S: Malignant transformation of a multiple cartilaginous exostosis - a case report. Int Orthop 1997, 21:133-136.

16. Cook A, Raskind W, Blanton SH, Pauli RM, Gregg RG, Francomano CA, Puffenberger E, Conrad EU, Schmale G, Schellenberg G, Wijsman $E$, Hecht JT, Wells D, Wagner MJ: Genetic heterogeneity in families with hereditary multiple exostoses. Am J Hum Genet 1993, 53:7I-79.

17. Ahn J, Ludecke HJ, Lindow S, Horton WA, Lee B, Wagner MJ, Horsthemke B, Wells DE: Cloning of the putative tumour suppressor gene for hereditary multiple exostoses (EXTI). Nature Genet 1995, II:I37-143.

18. Wuyts W, Van Hul W, Wauters J, Nemtsova M, Reyniers E, Van Hul E, De Boulle K, De Vries BBA, Hendrickx J, Herrygers I, Bossuyt P, Balemans W, Fransen E, Vits L, Coucke P, Nowak NJ, Shows TB, Mallet L, Van den Ouweland AMW, McGaughran J, Halley DJJ, Willems P: Positional cloning of a gene involved in hereditary multiple exostoses. Hum Mol Genet 1996, 5: 1547-I 557.

19. Stickens D, Clines G, Burbee D, Ramos P, Thomas S, Hogue D, Hecht JT, Lovett M, Evans GA: The EXT2 multiple exostoses gene defines a family of putative tumour suppressor genes. Nature Genet 1996, 14:25-32

20. Le Merrer M, Legeai-Mallet L, Jeannin PM, Horsthemke B, Schinzel A, Plauchu $\mathrm{H}$, Toutain A, Achard F, Munnich A, Maroteaux P: A gene for hereditary multiple exostoses maps to chromosome 19p. Hum Mol Genet 1994, 3:717-722.

2I. Signori E, Massi E, Matera MG, Poscente M, Gravina C, Falcone G, Rosa MA, Rinaldi M, Wuyts W, Seripa D, Dallapiccola B, Fazio VM: A combined analytical approach reveals novel EXTI/2 gene mutations in a large cohort of Italian multiple osteochondromas patients. Genes Chromosomes Cancer 2007, 46:470-477.

22. Vink GR, White SJ, Gabelic S, Hogendoorn PC, Breuning MH, Bakker E: Mutation screening of EXTI and EXT2 by direct sequence analysis and MLPA in patients with multiple osteochondromas: splice site mutations and exonic deletions account for more than half of the mutations. Eur J Hum Genet 2004, 13(4):470-474.

23. White SJ, Vink GR, Kriek M, Wuyts W, Schouten J, Bakker B, Breuning $\mathrm{MH}$, den Dunnen JT: Two-color multiplex ligation-dependent probe amplification: detecting genomic rearrangements in hereditary multiple exostoses. Hum Mutat 2004, 24:86-92

24. Ludecke HJ, Ahn J, Lin X, Hill A, Wagner MJ, Schomburg L, Horsthemke B, Wells DE: Genomic organization and promotor structure of the human EXTI gene. Genomics 1997, 40:35I-354.

25. Raskind WH, Conrad EU III, Matsushita M, Wijsman EM, Wells DE, Chapman N, Sandell LJ, Wagner M, Houck J: Evaluation of locus heterogeneity and EXTI mutations in 34 families with hereditary multiple exostoses. Hum Mutat 1998, II:231-239.

26. Legeai-Mallet L, Margaritte-Jeannin P, Lemdani M, Le Merrer M, Plauchu $\mathrm{H}$, Maroteaux P, Munnich A, Clerget-Darpoux F: An extension of the admixture test for the study of genetic heterogeneity in hereditary multiple exostoses. Hum Genet 1997, 99:298-302.
27. Wuyts W, Van Hul W: Molecular basis of multiple exostoses: mutations in the EXTI and EXT2 genes. Hum Mutat 2000, 15:220-227.

28. Seki H, Kubota T, Ikegawa S, Haga N, Fujioka F, Ohzeki S, Wakui K, Yoshikawa $\mathrm{H}$, Takaoka K, Fukushima $Y$ : Mutation frequencies of EXTI and EXT2 in 43 Japanese families with hereditary multiple exostoses. Am J Med Genet 200I, 99:59-62.

29. Wuyts W, Van Hul W, De Boulle K, Hendrickx J, Bakker E, Vanhoenacker F, Mollica F, Ludecke HJ, Sitki Sayli B, Pazzaglia UE, Mortier G, Hamel B, Conrad EU, Matsushita M, Raskind WH, Willems PJ: Mutations in the EXTI and EXT2 genes in hereditary multiple exostoses. Am J Hum Genet 1998, 62:346-354.

30. Xu L, Xia J, Jiang H, Zhou J, Li H, Wang D, Pan Q, Long Z, Fan C, Deng $\mathrm{HX}$ : Mutation analysis of hereditary multiple exostoses in the Chinese. Hum Genet 1999, 105:45-50.

3I. Park KJ, Shin KH, Ku JL, Cho TJ, Lee SH, Choi IH, Phillipe C, Monaco $A P$, Porter DE, Park JG: Germline mutations in the EXTI and EXT2 genes in Korean patients with hereditary multiple exostoses. J Hum Genet 1999, 44:230-234.

32. Francannet $C$, Cohen-Tanugi A, Le Merrer M, Munnich A, Bonaventure J, Legeai-Mallet L: Genotype-phenotype correlation in hereditary multiple exostoses. J Med Genet 200I, 38:430-434.

33. Cheung PK, McCormick C, Crawford BE, Esko JD, Tufaro F, Duncan G: Etiological point mutations in the hereditary multiple exostoses gene EXTI: a functional analysis of heparan sulfate polymerase activity. Am J Hum Genet 200I, 69:55-66.

34. Porter DE, Lonie L, Fraser M, Dobson-Stone C, Porter JR, Monaco AP, Simpson AH: Severity of disease and risk of malignant change in hereditary multiple exostoses. A genotype-phenotype study. J Bone Joint Surg Br 2004, 86: 104I-1046.

35. Alvarez C, Tredwell S, De VM, Hayden M: The genotype-phenotype correlation of hereditary multiple exostoses. Clin Genet 2006, 70:122-130.

36. Alvarez CM, De Vera MA, Heslip TR, Casey B: Evaluation of the anatomic burden of patients with hereditary multiple exostoses. Clin Orthop Relat Res 2007, 462:73-79.

37. Jager M, Westhoff B, Portier S, Leube B, Hardt K, Royer-Pokora B, Gossheger G, Krauspe R: Clinical outcome and genotype in patients with hereditary multiple exostoses. J Orthop Res 2007, 25:|54|-|55|.

38. Hameetman L, Szuhai K, Yavas A, Knijnenburg J, van Duin M, Van Dekken H, Taminiau AH, Cleton-Jansen AM, Bovee JV, Hogendoorn PC: The role of EXTI in nonhereditary osteochondroma: identification of homozygous deletions. J Natl Cancer Inst 2007, 99:396-406.

39. Bovée JVMG, Cleton-Jansen AM, Wuyts W, Caethoven G, Taminiau AHM, Bakker E, Van Hul W, Cornelisse C], Hogendoorn PCW: EXT-mutation analysis and loss of heterozygosity in sporadic and hereditary osteochondromas and secondary chondrosarcomas. Am J Hum Genet 1999, 65:689-698.

40. Bridge JA, Nelson M, Orndal C, Bhatia P, Neff JR: Clonal karyotypic abnormalities of the hereditary multiple exostoses chromosomal loci 8q24.I (EXTI) and I IpII-I2 (EXT2) in patients with sporadic and hereditary osteochondromas. Cancer 1998, 82:1657-1663.

4I. Mertens F, Rydholm A, Kreicbergs A, Willen H, Jonsson K, Heim S, Mitelman F, Mandahl N: Loss of chromosome band 8q24 in sporadic osteocartilaginous exostoses. Genes Chromosomes Cancer 1994, 9:8-12.

42. Feely MG, Boehm AK, Bridge RS, Krallman PM, Neff JR, Nelson M, Bridge JA: Cytogenetic and molecular cytogenetic evidence of recurrent 8q24.1 loss in osteochondroma. Cancer Genet Cytogenet 2002, 137:102-107.

43. Hall CR, Cole WG, Haynes R, Hecht JT: Reevaluation of a genetic model for the development of exostosis in hereditary multiple exostosis. Am J Med Genet 2002, I I 2: I-5.

44. Lin X, Gan L, Klein WH, Wells DE: Expression and functional analysis of mouse EXTI, a homolog of the human multiple exostoses type I gene. Biochem Biophys Res Commun 1998, 248:738-743.

45. Stickens D, Evans GA: Isolation and characterization of the murine homolog of the human EXT2 multiple exostoses gene. Biochem Mol Med 1997, 61:16-21.

46. Stickens D, Brown D, Evans GA: EXT genes are differentially expressed in bone and cartilage during mouse embryogenesis. Dev Dyn 2000, 2 I 8:452-464. 
47. Hameetman L, David G, Yavas A, White SJ, Taminiau AHM, CletonJansen AM, Hogendoorn PCW, Bovée JVMG: Decreased EXT expression and intracellular accumulation of HSPG in osteochondromas and peripheral chondrosarcomas. J Pathol 2007, 21 I:399-409.

48. Lind T, Tufaro F, McCormick C, Lindahl U, Lidholt K: The putative tumor suppressors EXTI and EXT2 are glycosyltransferases required for the biosynthesis of heparan sulfate. J Biol Chem 1998, 273:26265-26268.

49. McCormick C, Leduc Y, Martindale D, Mattison K, Esford LE, Dyer AP, Tufaro F: The putative tumour suppressor EXTI alters the expression of cell-surface heparan sulfate. Nature Genet 1998, 19:158-161.

50. Simmons AD, Musy MM, Lopes CS, Hwang LY, Yang YP, Lovett M: A direct interaction between EXT proteins and glycosyltransferases is defective in hereditary multiple exostoses. Hum Mol Genet 1999, 8:2155-2164.

5I. McCormick C, Duncan G, Goutsos KT, Tufaro F: The putative tumor suppressors EXTI and EXT2 form a stable complex that accumulates in the golgi apparatus and catalyzes the synthesis of heparan sulfate. Proc Natl Acad Sci USA 2000, 97:668-673.

52. Bellaiche $Y$, The I, Perrimon N: Tout-velu is a drosophila homologue of the putative tumour suppressor EXTI and is needed for Hh diffusion. Nature 1998, 394:85-88.

53. The I, Bellaiche $\mathrm{Y}$, Perrimon $\mathrm{N}$ : Hedgehog movement is regulated through tout velu -dependant synthesis of a heparan sulfate proteoglycan. Mol Cell 1999, 4:633-639.

54. Toyoda H, Kinoshita-Toyoda A, Selleck SB: Structural analysis of glycosaminoglycans in drosophila and caenorhabditis elegans and demonstration that tout-velu, a drosophila gene related to EXT tumor suppressors, affects heparan sulfate in vivo. J Biol Chem 2000, 275:2269-2275

55. Han C, Belenkaya TY, Khodoun M, Tauchi M, Lin X, Lin X. Distinct and collaborative roles of Drosophila EXT family proteins in morphogen signalling and gradient formation. Development 2004, I 31:1563-1575.

56. Takei Y, Ozawa Y, Sato M, Watanabe A, Tabata T: Three Drosophila EXT genes shape morphogen gradients through synthesis of heparan sulfate proteoglycans. Development 2004 , 131:73-82.

57. Hameetman L, Rozeman LB, Lombaerts M, Oosting J, Taminiau AHM Cleton-Jansen AM, Bovée JVMG, Hogendoorn PCW: Peripheral chondrosarcoma progression is accompanied by decreased Indian Hedgehog (IHH) signalling. J Pathol 2006, 209:50 I-5II.

58. Benoist-Lasselin C, de Margerie E, Gibbs L, Cormier S, Silve C, Nicolas G, Lemerrer M, Mallet JF, Munnich A, Bonaventure J, Zylberbers $\mathrm{L}$, Legeai-Mallet L: Defective chondrocyte proliferation and differentiation in osteochondromas of MHE patients. Bone 2006 39:17-26.

59. Bovée JVMG, Van den Broek LJCM, Cleton-Jansen AM, Hogendoorn PCW: Up-regulation of PTHrP and Bcl-2 expression characterizes the progression of osteochondroma towards peripheral chondrosarcoma and is a late event in central chondrosarcoma. Lab Invest 2000, 80:1925-1933.

60. Hameetman L, Kok P, Eilers PHC, Cleton-Jansen AM, Hogendoorn PCW, Bovée JVMG: The use of Bcl-2 and PTHLH immunohistochemistry in the diagnosis of peripheral chondrosarcoma in a clinicopathological setting. Virchows Arch 2005, 446:430-437.

61. Hameetman L, Bovée JVMG, Taminiau AHM, Kroon HM, Hogendoorn PCW: Multiple Osteochondromas: Clinicopathological and Genetic Spectrum and Suggestions for Clinical Management. Hereditary Cancer in Clinical Practice 2004, 2:161-173.

62. Wuyts W, Radersma R, Storm K, Vits L: An optimized DHPLC protocol for molecular testing of the EXTI and EXT2 genes in hereditary multiple osteochondromas. Clin Genet 2005 68:542-547.

63. Lonie L, Porter DE, Fraser M, Cole T, Wise C, Yates L, Wakeling E, Blair E, Morava E, Monaco AP, Ragoussis J: Determination of the mutation spectrum of the EXTI/EXT2 genes in British Caucasian patients with multiple osteochondromas, and exclusion of six candidate genes in EXT negative cases. Hum Mutat 2006, 27: 1160

64. Geirnaerdt MJ, Hogendoorn PCW, Bloem JL, Taminiau AHM, Van der Woude $\mathrm{HJ}$ : Cartilaginous tumors: fast contrast-enhanced MR imaging. Radiology 2000, 21 4:539-546.
65. Feldman F, Vanheertum R, Saxena C: I 8Fluoro-deoxyglucose positron emission tomography evaluation of benign versus malignant osteochondromas: preliminary observations. J Comput Assist Tomogr 2006, 30:858-864.

66. Glick R, Khaldi L, Ptaszynski K, Steiner GC: Dysplasia epiphysealis hemimelica (Trevor disease): a rare developmental disorder of bone mimicking osteochondroma of long bones. Hum Pathol 2007, 38: I265-I 272.

67. Bovée JVMG, Hameetman L, Kroon HM, Aigner T, Hogendoorn PCW: EXT-related pathways are not involved in pathogenesisof Dysplasia Epiphysealis Hemimelica and Metachondromatosis. J Pathol 2006, 209:4II-4I9.

68. Murphey MD, Choi JJ, Kransdorf MJ, Flemming DJ, Gannon FH: Imaging of osteochondroma: variants and complications with radiologic-pathologic correlation. RadioGraphics 2000, 20:1407-| 434 .

69. Silverman FN: Dysplasia epiphysealis hemimelica. Semin Roentgenol 1989, 24:246-258

70. Ippolito E, Tudisco C: Dysplasia epiphysealis hemimelica. Clinical, histological and histochemical features. Ital ] Orthop Traumatol 1983, 9:101-107.

7I. Kuo RS, Bellemore MC, Monsell FP, Frawley K, Kozlowski K: Dysplasia epiphysealis hemimelica: clinical features and management. J Pediatr Orthop 1998, 18:543-548.

72. Bassett GS, Cowell HR: Metachondromatosis. Report of four cases. J Bone Joint Surg Am 1985, 67:8I I-8I4.

73. Herman TE, Chines A, McAlister WH, Gottesman GS, Eddy MC Whyte MP: Metachondromatosis: report of a family with facial features mildly resembling trichorhinophalangeal syndrome. Pediatr Radiol 1997, 27:436-44|.

74. Kennedy LA: Metachondromatosis. Radiology 1983, | 48: | |7-| I8.

75. Mertens F, Unni KK: Enchondromatosis: Ollier disease and Maffucci syndrome. In World Health Organization Classification of Tumours. Pathology and genetics of tumours of soft tissue and bone Edited by: Fletcher CDM, Unni KK and Mertens F. Lyon, IARC Press; 2002:356-357.

76. van Lerberghe E, Van Damme B, van Holsbeeck M, Burssens A, Hoogmartens $M$ : Case report 626: Osteosarcoma arising in a solitary osteochondroma of the femur. Skeletal Radiol 1990 19:594-597.

77. Lamovec J, Spiler M, Jevtic V: Osteosarcoma arising in a solitary osteochondroma of the fibula. Arch Pathol Lab Med 1999, | 23:832-834.

78. Matsuno T, Ichioka Y, Yagi T, Ishii S: Spindle-cell sarcoma in patients who have osteochondromatosis. A report of two cases. J Bone Joint Surg [Am] I988, 70:137-I4I.

79. Bovée JVMG, Sakkers RJ, Geirnaerdt MJ, Taminiau AH, Hogendoorn PCW: Intermediate grade osteosarcoma and chondrosarcoma arising in an osteochondroma. A case report of a patient with hereditary multiple exostoses. J Clin Pathol 2002, 55:226-229.

80. Tsuchiya $\mathrm{H}$, Morikawa $\mathrm{S}$, Tomita $\mathrm{K}$ : Osteosarcoma arising from a multiple exostoses lesion: case report. Jpn J Clin Oncol 1990, 20:296-298.

8I. Bertoni F, Present D, Bacchini P, Picci P, Pignatti G, Gherlinzoni F, Campanacci M: Dedifferentiated peripheral chondrosarcomas, a report of seven cases. Cancer 1989, 63:2054-2059.

82. Staals EL, Bacchini P, Mercuri M, Bertoni F: Dedifferentiated chondrosarcomas arising in preexisting osteochondromas. J Bone Joint Surg Am 2007, 89:987-993.

83. Akita S, Murase T, Yonenobu K, Shimada K, Masada K, Yoshikawa $\mathrm{H}$ : Long-term results of surgery for forearm deformities in patients with multiple cartilaginous exostoses. J Bone Joint Surg Am 2007, 89:1993-1999.

84. Matsubara H, Tsuchiya H, Sakurakichi K, Yamashiro T, Watanabe $\mathrm{K}$, Tomita $\mathrm{K}$ : Correction and lengthening for deformities of the forearm in multiple cartilaginous exostoses. J Orthop Sci 2006, I I:459-466.

85. Donati D, El Ghoneimy A, Bertoni F, Di Bella C, Mercuri M: Surgical treatment and outcome of conventional pelvic chondrosarcoma. Journal of Bone and Joint Surgery-British Volume 2005, 87(I I): I527-I530

86. Evans HL, Ayala AG, Romsdahl MM: Prognostic factors in chondrosarcoma of bone. A clinicopathologic analysis with emphasis on histologic grading. Cancer 1977, 40:8|8-83।. 